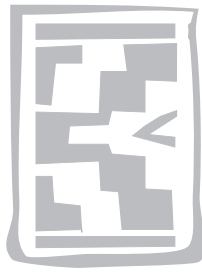

\title{
Pentastomid parasites in fish in the Olifants and Incomati River systems, South Africa
}

\author{
WILMIEN J. LUUS-POWELL ${ }^{1 *}$, ANTOINETTE JOOSTE ${ }^{1}$ and KERSTIN JUNKER ${ }^{2}$
}

\begin{abstract}
LUUS-POWELL, WILMIEN J., JOOSTE, ANTOINETTE \& JUNKER, KERSTIN. 2008. Pentastomid parasites in fish in the Olifants and Incomati River systems, South Africa. Onderstepoort Journal of Veterinary Research, 75:323-329

During parasitological field surveys of freshwater fish, sebekiid and subtriquetrid pentastome larvae were recovered from the body cavity or swim bladder of several fish species from various localities in Limpopo and Mpumalanga Provinces, South Africa. Sebekia wedli was recovered from the body cavity of Marcusenius macrolepidotus (Mormyridae) from Flag Boshielo Dam, Limpopo Province, and Alofia sp. and Subtriquetra rileyi were found in the swim bladder of Oreochromis mossambicus (Cichlidae) from the Phalaborwa Barrage, Limpopo Province. The latter species was also collected from the swim bladder of $O$. mossambicus in dams in the Phalaborwa region and the Ga-Selati River, Limpopo Province. A single specimen of Sebekia okavangoensis was present in the body cavity of Clarias gariepinus (Clariidae) in a dam on a sugarcane farm in the Komatipoort region, Mpumalanga Province. Pentastomid infections in the Mormyridae and Clariidae represent new host records.
\end{abstract}

Keywords: Alofia sp., Clarias gariepinus, Marcusenius macrolepidotus, Oreochromis mossambicus, Pentastomida, Sebekia okavangoensis, Sebekia wedli, South Africa, Subtriquetra rileyi

\section{INTRODUCTION}

The Pentastomida represent an ancient taxon, comprising some 131 species in seven families (Almeida \& Christoffersen 1999). Adults of most species inhabit the nasal passageways and lungs of snakes, lizards and crocodilians, while others are found in the air sacs of gulls and terns, and in the nasopharynx and sinuses of canids and felids (Bakke 1972; Banaja, James \& Riley 1975; Riley 1986). Two spe-

* Author to whom correspondence is to be directed. E-mail: powellw@ul.ac.za

1 Department of Biodiversity, University of Limpopo (Turfloop Campus), Private Bag X1106, Sovenga, 0727 South Africa

2 Department of Veterinary Tropical Diseases, University of Pretoria, Private Bag X04, Onderstepoort, 0110 South Africa

Accepted for publication 22 August 2008-Editor cies, Raillietiella bufonis and Raillietiella indica, use amphibians as final hosts (Ali, Riley \& Self 1982). The pentastomid life cycle usually includes a vertebrate intermediate host in which larvae undergo several moults to reach the infective stage (Riley 1986; Winch \& Riley 1986a; Riley \& Huchzermeyer 2000), but insects have been reported as intermediate hosts of some raillietiellid parasites, while Reighardia sternae, a parasite of gulls, has a direct lifecycle (Banaja et al. 1975; Riley 1986).

Two families of pentastomids, Sebekidae and Subtriquetridae, use various freshwater fish species as intermediate hosts (Fain 1961; Overstreet, Self \& Vliet 1985; Winch \& Riley 1986a, b; Junker, Boomker \& Booyse 1998). The sebekiid genera, Agema, Alofia, Leiperia and Selfia, have to date only been recorded from crocodilian final hosts, but a single Sebekia species is also thought to mature in a che- 
Ionian host (Dukes, Shealy \& Rogers 1971; Riley, Spratt \& Winch 1990). The sebekiids Diesingia and Pelonia, on the other hand, have hitherto been reported exclusively from chelonian final hosts (Sambon 1922; Overstreet et al. 1985; Junker \& Boomker 2002). Adults of the Subtriquetridae are known from crocodilians only (Riley et al. 1990).

In South Africa infective larvae of Sebekia wedli, Leiperia cincinnalis and Subtriquetra rileyi have been reported from the cichlids Tilapia rendalli (redbreast tilapia) and Oreochromis mossambicus (Mozambique tilapia) from the Phabeni Dam in the Kruger National Park (KNP) (Junker et al. 1998). Junker, Boomker \& Bolton (1999) recorded the Nile crocodile, Crocodylus niloticus, as the definitive host of $S$. wedli and L. cincinnalis, as well as of Alofia nilotici, Alofia simpsoni, Sebekia cesarisi and Sebekia okavangoensis in South Africa. The final host of S. rileyi is as yet unknown. The pentastomid parasites included in this publication are products of a number of parasitological studies on freshwater fish from several localities in two provinces of South Africa.

\section{MATERIALS AND METHODS}

During fish health surveys, a total of 1047 fish, belonging to 14 species were collected at nine localities in South Africa and examined for parasites (Tables 1 and 2).

Fish were captured using gill nets of stretched mesh sizes, ranging from $30-120 \mathrm{~mm}$, and transported live to the field laboratory where they were kept in containers with well aerated water. Immediately before dissection, fish were killed by decapitation. Encysted larvae were removed from their cysts and placed in water to unfold. In order to prevent them from contracting, they were fixed by adding small quantities of $70 \%$ ethanol to the water over a period of approximately $1 \mathrm{~h}$, after which they were transferred to $70 \%$ ethanol.

Pentastomids were mounted and cleared in Hoyer's medium for identification. Measurements were taken from whole mounted specimens according to the schematic layout proposed by Riley et al. (1990). Hook and oral cadre morphology, combined with the number of annuli, were used as identification criteria.

The ecological terms prevalence, mean intensity and abundance are used in accordance with Bush, Lafferty, Lotz \& Shostak (1997). Standard deviation was not calculated, since too few specimens were collected which renders standard deviation values meaningless (Rózsa, Reiczigel \& Majoros 2000).

\section{RESULTS}

Pentastomid larvae were encountered at four localities in the Olifants River drainage system in Limpopo Province (Table 2). Eight encysted infective $S$. wedIi larvae were collected from the body cavity of five of 29 Marcusenius macrolepidotus (Mormyridae) (bulldog) in Flag Boshielo Dam, constituting a new intermediate host record for this parasite. While a single cyst was located on the swim bladder, the remainder were found between fat deposits on the mesenteries. Cysts had a yellowish colour and closely resembled those of Clinostomum metacercariae, although slightly smaller in size. No free-living larvae were detected in the swim bladder. The prevalence of infection was $17.2 \%$, with a mean intensity of 1.6 (range 1-3) and an abundance of 0.3 .

Subtriquetra rileyi was free-living in the swim bladder of $O$. mossambicus from dams in the PIC region. The prevalence of infection was $6.3 \%$, the mean intensity 1.9 (range 1-6) and the abundance 0.1 . No pentastomid larvae were recovered from sharptooth catfish, Clarias gariepinus (Clariidae), the only other host examined at these sites at the time (Table 2).

At the Phalaborwa Barrage, S. rileyi, and a total of three infective larvae of an Alofia sp. were recovered from $O$. mossambicus. Concurrent infections of $S$. rileyi and Alofia sp. occurred in two hosts, with the former moving freely in the swim bladder while the Alofia sp. was encapsulated. Combined, the two species had a prevalence of $30 \%$, a mean intensity of 2.4 (range 1-5) and an abundance of 0.7. Clarias gariepinus and Labeo rosae (Cyprinidae) examined at this site harboured no pentastomid larvae (Table 2). This is the first published record of an Alofia species from fish intermediate hosts in South Africa.

In the Ga-Selati River, three S. rileyi larvae were recovered from one $O$. mossambicus of 36 examined, resulting in a prevalence of $2.7 \%$, and an abundance of 0.08 . Larvae were moving freely in the swim bladder. No pentastomid larvae were found in C. gariepinus at this site (Table 2).

With respect to the Incomati River drainage system, Mpumalanga Province, a single infective larva of $S$. okavangoensis was encysted on the mesenteries of C. gariepinus, from a dam on a sugarcane farm in the Komatipoort region. This is the first report of $C$. gariepinus as intermediate host of a pentastomid. 


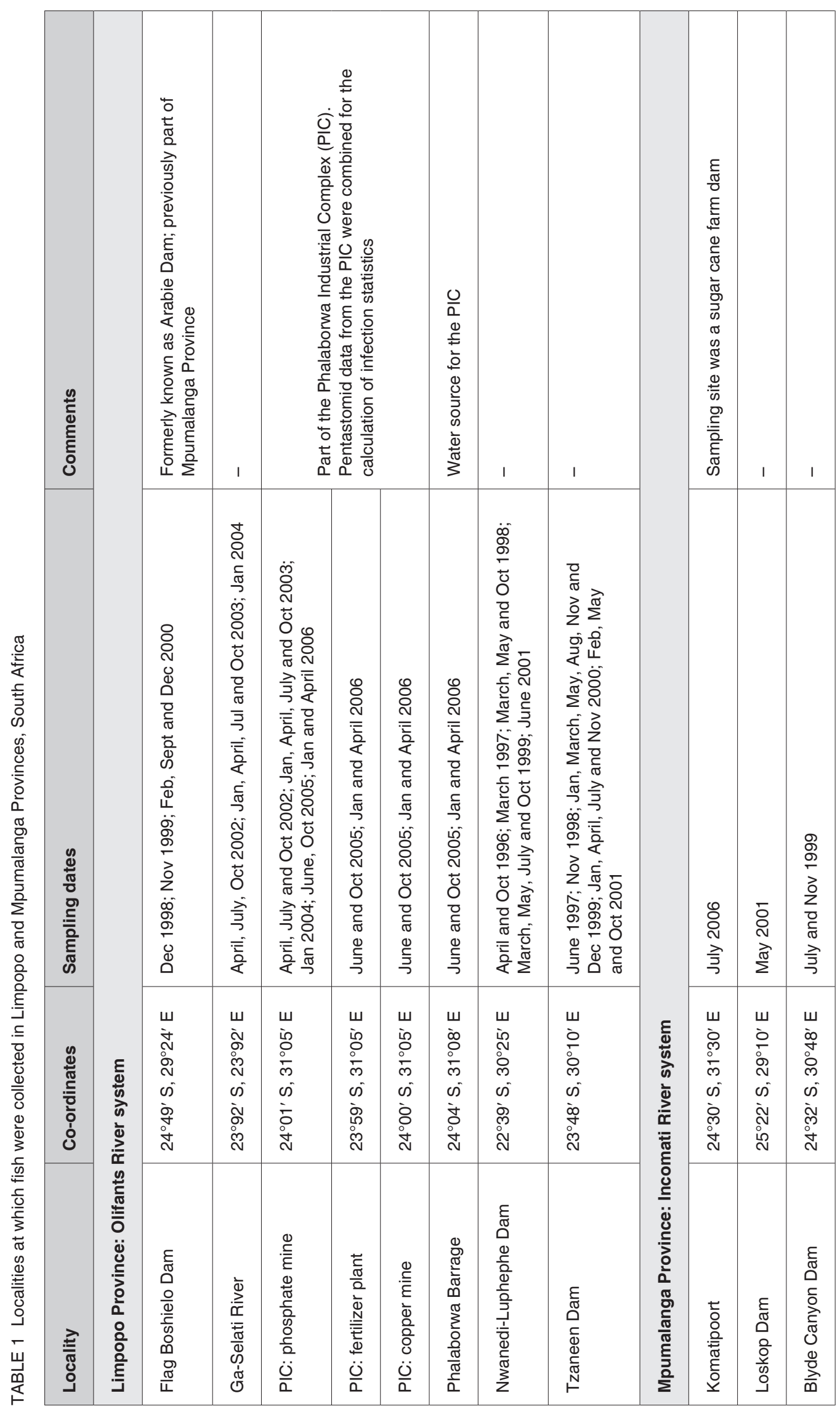




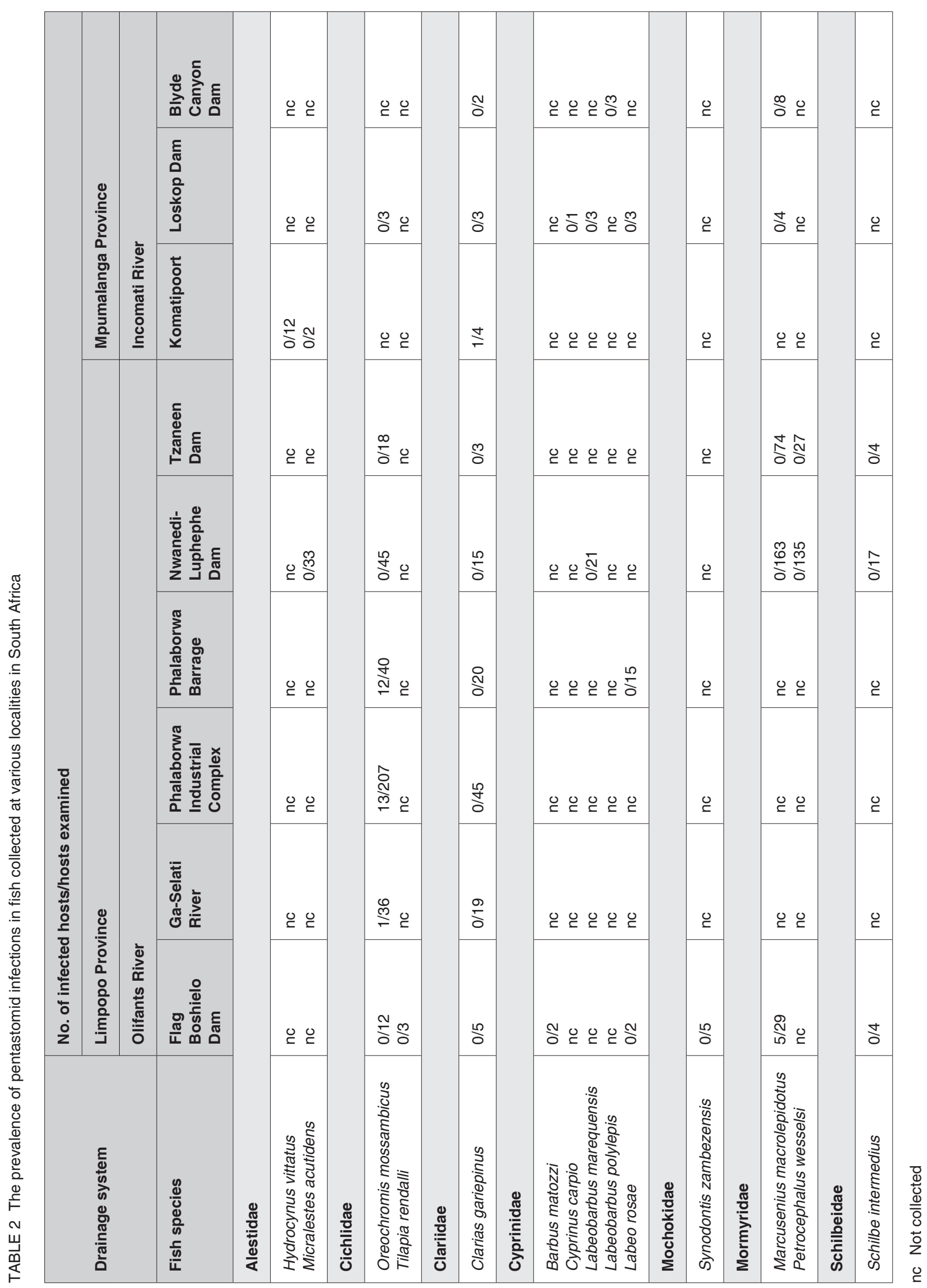




\section{DISCUSSION}

The fact that S. wedli, S. okavangoensis and the Alofia sp. had reached the final larval stage, as evidenced by double hooks and rows of annular spines typical for infective sebekiid larvae (Winch \& Riley 1986a), confirms that M. macrolepidotus, C. gariepinus and $O$. mossambicus are indeed the respective true intermediate hosts for these pentastomids. Similarly, Winch \& Riley (1986a) found only the infective stage of Sebekia to be encysted.

Morphological characteristics of infective larvae of $S$. wedli from M. macrolepidotus correspond well with those recorded from $O$. mossambicus and $T$. rendalli (Junker et al. 1998). Ranging from 73-77, the number of annuli in infective larvae from $M$. macrolepidotus was similar to that observed in the latter hosts, namely 71-76 (Junker et al. 1998). Other characteristics that support the identification of $S$. wedli were the single row of chloride cell pore caps on the anterior border of the annuli and the overall appearance of the oral cadre. The latter is readily distinguished from congeneric African species by appearing open anteriorly and having a less pronounced ovoid profile (Riley \& Huchzermeyer 1995).

The arrangement of the chloride cell pore caps in an irregular field at the anterior border of the annuli, about $2-3$ cells deep, and the mitre-shaped appearance of the oral cadre, observed in the specimen from $C$. gariepinus confirm its identification as $S$. okavangoensis as described by Riley \& Huchzermeyer (1995).

All infective Sebekia and Alofia larvae found during this study were encysted, the cysts being attached to either the swim bladder or the mesenteries. Conversely, Junker et al. (1998) recorded encysted as well as free-living infective $S$. wedli larvae from $T$. rendalli and $O$. mossambicus. The majority were, however, encysted and the authors speculated that free-living infective larvae had only recently moulted into this developmental stage. Junker et al. (1998) recovered $S$. wedli from the swim bladder only, and not from the mesenteries. They did, however, collect encysted infective larvae of another sebekiid, $L$. cincinnalis from this site in $T$. rendalli and $O$. mossambicus.

The literature suggests that sebekiids may occupy a number of sites in their intermediate hosts, and Overstreet et al. (1985) reported infective larvae of Sebekia mississippiensis under the connective tissues lining muscle, kidney, liver and swim bladder of a variety of fish intermediate hosts.
Sebekia wedli larvae appear to be host specific in Flag Boshielo Dam, as none of the other seven fish species examined at the time, including 12 O. mossambicus and three $T$. rendalli, harboured pentastomid larvae (Table 2). Sebekia wedli had a relatively high prevalence of $40.5 \%$ in $T$. rendalli in the KNP, but only three of 119 O. mossambicus harboured this pentastome (Junker et al. 1998). Hence, it is possible that the sample size with respect to the other hosts in Flag Boshielo Dam was too small to detect infection.

Although mormyrids were studied intensively at Nwanedi-Luphephe and Tzaneen Dams, Limpopo Province, and Loskop and Blyde Canyon Dams, Mpumalanga Province (Table 2), pentastomid larvae were only recovered from $M$. macrolepidotus from Flag Boshielo Dam.

Flag Boshielo Dam has a large population of Nile crocodiles. These crocodilians have long been established as a final host of $S$. wedli (Sambon 1922), and Junker et al. (1999) reported this pentastomid from Nile crocodiles in South Africa. Mormyrids are bottom feeders, favouring the muddy bottomed margins of rivers and floodplains (Skelton 2001), and are thus likely to ingest pentastome eggs, which are shed in crocodile faeces, and settle onto the bottom substrate. It remains a matter of speculation as to why $S$. wedli was not observed in intermediate hosts at any of the other dams, since both Loskop and Blyde Canyon Dams, as well as Tzaneen Dam also support crocodile populations. Possibly sample sizes at all these Dams were too small to detect pentastome infections. Prevalence data on pentastomids in Nile corocodiles in any of the above dams, including Flag Boshielo, are lacking.

Clarias gariepinus constitutes an important component of the diet of Nile crocodiles (Guggisberg 1972; Whitfield \& Blaber 1979), and its own feeding habits would readily expose it to ingesting pentastome eggs. Riley \& Huchzermeyer (2000) noted that Clarias spp. were common in swamp forest pools in the northern Congo Republic and postulated that it might serve as intermediate host for the pentastomids, Agema silvaepalustris, Alofia parva and S. okavangoensis, that were recovered from swamp forest dwarf crocodiles, Osteolaemus tetraspis, in that region. However, no proof of the role of Clarias in the transmission of pentastomids has so far been presented. The prevalence of infection in C. gariepinus is low and only one of four hosts at the Komatipoort locality was infected, while a total of 112 collected at eight additional localities did not habour the parasite (Table 2). Ten $C$. gariepinus from the KNP also har- 
boured no pentastomids (Junker, unpublished data 1996). Winch \& Riley (1986b) concluded that the absence of Subtriquetra subtriquetra in bottomfeeding Tilapia spp. in Trinidad, despite its presence in Aequidens pulcher, another bottom-feeder in the same reservoir, was probably due to an immune response. This could also be an explanation for the low prevalence of pentastomids in $C$. gariepinus.

To date, several fish species belonging to a number of families world-wide have been recorded as intermediate hosts of sebekiids, namely Sebekia oxycephala in A. pulcher (Cichlidae) (blue acra) and Tilapia sp. (Cichlidae) in Trinidad and Gambusia affinis (Poeciliidae) (mosquitofish) in Florida (Boyce, Cardeilhac, Lane, Buergelt \& King 1984; Winch \& Riley 1986a). Fundulus grandis (Fundulidae) (gulf killifish), Lepomis macrochirus (Centrarchidae) (bluegill), Micropogonias undulatus (Sciaenidae) (Atlantic croaker), Micropterus salmoides (Centrarchidae) (largemouth bass) and Xiphophorus helleri (Poeciliidae) (swordtail) are confirmed intermediate hosts for Sebekia mississippiensis (Overstreet et al. 1985). Fain (1961) lists Alestes macrophthalmus (Alestidae) (torpedo robber), Bathybates ferox (Cichlidae), Chrysichthys brachynema (Claroteidae) (salmontail catfish), Chrysichthys mabusi (Claroteidae), Lates microlepis (Latidae) (forktail lates), Lates niloticus (Latidae) (Nile perch), Mastacembelus sp. (Mastacembelidae) and Oreochromis niloticus (= Tilapia nilotica) (Cichlidae) (Nile tilapia) as intermediate hosts of $L$. cincinnalis in Central Africa. The latter was also present in Serranochromis meridianus (Cichlidae) (Lowveld largemouth) in South Africa (Junker 2002). Few data exist on the intermediate hosts of Subtriquetra, which has sofar been recovered from A. pulcher, O. mossambicus and T. rendalli (Winch \& Riley 1986b; Junker et al. 1998). Fain (1961) reports S. subtriquetra from Brazilian fish in general.

While $S$. rileyi has now been reported from intermediate fish hosts from several localities in South Africa, its final host has not been identified. According to Riley et al. (1990) adult subtriquetrids are exclusive to crocodilians, but adult $S$. rileyi were absent in crocodiles harbouring other pentastome infections in the KNP, suggesting the involvement of a different final host, perhaps piscivorous terrapins or birds (Junker 2002).

\section{ACKNOWLEDGEMENTS}

The Division for Research Development and Administration, University of Limpopo, is thanked for finan- cial assistance. The research at Phalaborwa was supported by a grant from the National Research Foundation of South Africa (Thuthuka Programme; TTK2004081000029). We are grateful to the Department of Biodiversity, University of Limpopo, for infrastructure and Messrs H.E. Hattingh and J. Theron for technical assistance during some of the field surveys.

\section{REFERENCES}

ALI, J.H., RILEY, J. \& SELF, J.T. 1982. Amphibians as definitive hosts for pentastomids: Railietiella bufonis n. sp. from Bufo lemur in Puerto Rico and a reassessment of Railietiella indica Gedoelst, 1921. Systematic Parasitology, 4:279-284.

ALMEIDA, DE OLIVEIRA, W. \& CHRISTOFFERSEN, M.L. 1999. A cladistic approach to relationships in Pentastomida. Journal of Parasitology, 85:695-704.

BAKKE, T.A. 1972. Reighardia sternae (Diesing, 1864) Ward, 1899 (Pentastomida: Cephalobaenida) from the common gull (Larus canus L.) in a Norwegian locality. Norwegian Journal of Zoology, 20:273-277.

BANAJA, A.A., JAMES, J.L. \& RILEY, J. 1975. An experimental investigation of a direct life-cycle in Reighardia sternae (Diesing, 1864), a pentastomid parasite of the herring gull (Larus argentatus). Parasitology, 71:493-503.

BOYCE, W., CARDEILHAC, P., LANE, T., BUERGELT, C. \& KING, M. 1984. Sebekiosis in captive alligator hatchlings. Journal of the American Veterinary Medical Association, 185:1419-1420.

BUSH, A.O., LAFFERTY, K.D., LOTZ, J.M. \& SHOSTAK, A.W. 1997. Parasitology meets ecology on its own terms: Margolis et al. revisited. Journal of Parasitology, 83:575-583.

DUKES, G.H., SHEALY, R.M. \& ROGERS, W.A. 1971. Sebekia oxycephala (Pentastomida) in largemouth bass from Lake St. John, Concordia Parish, Louisiana. Journal of Parasitology, 57:1028.

FAIN, A. 1961. Les pentastomides de l' Afrique Centrale. Annales du Musée Royale de l'Afrique Centrale, Série 8, 92:1-115.

GUGGISBERG, C.A. 1972. Crocodiles. Cape Town: Purnell.

JUNKER, K., BOOMKER, J. \& BOOYSE, D.G. 1998. Pentastomid infections in cichlid fishes in the Kruger Natioanl Park, and description of the infective larva of Subtriquetra rileyi $\mathrm{n}$. sp. Onderstepoort Journal of Veterinary Research, 65:159-167.

JUNKER, K., BOOMKER, J. \& BOLTON, L. 1999. Pentastomid infections in the Nile crocodile (Crocodylus niloticus) in the Kruger National Park, South Africa, with a description of the males of Alofia simpsoni. Onderstepoort Journal of Veterinary Research, 66:65-71.

JUNKER, K. 2002. A study on the Pentastomida parasitising crocodilian and chelonian final hosts, with special emphasis on the South African pentastome fauna. Ph.D. thesis. University of Karlsruhe.

JUNKER, K. \& BOOMKER, J. 2002. Description of Pelonia africana n. g., n. sp. (Pentastomida: Sebekidae) from the lungs of Pelomedusa subrufa and Pelusios sinuatus (Chelonia) in South Africa. Onderstepoort Journal of Veterinary Research, 69:53-59.

OVERSTREET, R.M., SELF, J.T. \& VLIET, K.A. 1985. The pentastomid Sebekia mississippiensis sp. $\mathrm{n}$. in the American alligator and other hosts. Proceedings of the Helminthological Society of Washington, 52:266-277. 
RILEY, J. 1986. The biology of pentastomids. Advances in Parasitology, 25:45-128.

RILEY, J., SPRATT, D.M. \& WINCH, J.M. 1990. A revision of the genus Sebekia Sambon, 1922 (Pentastomida) from crocodilians with description of five new species. Systematic Parasitology, 16:1-25.

RILEY, J. \& HUCHZERMEYER, F.W. 1995. Pentastomid parasites of the family Sebekidae Fain 1961 in West African dwarf crocodiles Osteolaemus tetraspis Cope, 1851 from the Congo, with a description of Alofia parva n. sp. Onderstepoort Journal of Veterinary Research, 62:151-162.

RILEY, J. \& HUCHZERMEYER, F.W. 2000. Diet and lung parasites of swamp forest dwarf crocodiles (Osteolaemus tetraspis osborni) in the Northern Congo Republic. Copeia, 2:582-586.

RÓZSA, L., REICZIGEL, J. \& MAJOROS, G. 2000. Quantifying parasites in samples of hosts. Journal of Parasitology, 86: 228-232.
SAMBON, L.W. 1922. A synopsis of the family Linguatulidae. Journal of Tropical Medicine and Hygiene, 25:188-206; 391-428.

SKELTON, P.H. 2001. A complete guide to the freshwater fishes of Southern Africa. Halfway House: Southern Book Publishers (Pty) Ltd.

WHITFIELD, A.K. \& BLABER, S.J.M. 1979. Predation on Striped Mullet (Mugil cephalus) by Crocodylus niloticus at St. Lucia, South Africa. Coopeia, 2:266-269.

WINCH, J.M. \& RILEY, J. 1986a. Morphogenesis of larval Sebekia oxycephala (Pentastomida) from a South American crocodilian (Caiman sclerops) in experimentally infected fish. Zeitschrift für Parasitenkunde, 72:251-264.

WINCH, J.M. \& RILEY, J. 1986b. Studies on the behaviour, and development in fish, of Subtriquetra subtriquetra: a uniquely free-living pentastomid larva from a crocodilian. Parasitology, 93:81-98. 